\title{
Modification of Thionucleobases in Ionic Liquids
}

\author{
Xiaomei Hu, ${ }^{1}$ Bixian Zhang, ${ }^{2}$ Shijia Dong, ${ }^{1}$ and Yunfei Gao ${ }^{2}$ \\ ${ }^{1}$ School of Life and Science, Northeast Agricultural University, Harbin 150030, China \\ ${ }^{2}$ Heilongjiang Academy of Agricultural Sciences, Harbin 150086, China
}

Correspondence should be addressed to Xiaomei Hu; huxiaomei1982@163.com

Received 15 August 2014; Accepted 22 September 2014; Published 21 October 2014

Academic Editor: Joaquin Campos

Copyright (C) 2014 Xiaomei Hu et al. This is an open access article distributed under the Creative Commons Attribution License, which permits unrestricted use, distribution, and reproduction in any medium, provided the original work is properly cited.

\begin{abstract}
A simple method was established for the preparation of thio-substituted thionucleobases using room temperature ionic liquids (RTILs) such as 1-butyl-3-methylimidazolium trifluoroacetate $[\mathrm{BMIM}]^{+}\left[\mathrm{CF}_{3} \mathrm{COO}\right]^{-}$and 1-methoxyethyl-3-methylimidazolium trifluoroacetate $[\mathrm{MeOEtMIM}]^{+}\left[\mathrm{CF}_{3} \mathrm{COO}\right]^{-}$as solvents and catalysts without any other catalyst. These reactions proceeded efficiently in RTILs with excellent yield of products. RTILs can be recycled and reused effectively without further purification.
\end{abstract}

\section{Introduction}

Nucleoside chemistry is an important research area in drug development. Various kinds of chemical modified nucleobases, nucleosides, and oligonucleotides have biological activities. 6-Mercaptopurine and 6-thioguanine have been found in 1950s $[1,2]$. Nowadays, they are commonly used as clinical drugs for the treatment of leukaemia or inflammatory bowel disease. Elgemeie synthesized a series of nucleobase analogues [3]. 2-Thioalkylsubstituted purines and 6mercapto-9-substituted purines showed active antileukaemia in mice [4]. Another significant work was reported by Kumar. 6-Methylthioguanine has a certain function to trigger cell death [5]. Their work indicates that thio-substituted nucleobases have potential antitumors or anti-inflammatory activities.

However, one of the big problems associated with the nucleoside chemistry is the poor solubility of these nucleobase or nucleoside compounds in the commonly used organic solvents. There is an urgent need to develop alternative solvents and technologies. Ionic liquids provide an opportunity to solve this problem. Room temperature ionic liquids (RTILs) as "green solvents" have gained wide popularity in recent years for their increasing applications as they possess a number of interesting properties such as a widely accessible temperature range, low vapor pressure, and lack of flammability and ease of reuse. Therefore they are considered to be environmentally friendly reaction mediums
[6-8]. As 6-mercaptopurine and 6-thioguanine have been used as effective anticancer and anti-inflammatory drugs it is worthwhile to explore modified thionucleobases. Various RTILs have been prepared. A series of thio-substituted nucleobases were synthesized in RTILs and a possible mechanism was proposed.

\section{Experimental Section}

Chemicals were purchased from Alading Company (China) and Aldrich Company and were used as received. Mass spectrometry (APCI-MS) was carried out on a HewlettPackard 5989B quadrupole instrument. ${ }^{1} \mathrm{H}$ NMR spectra were recorded on a Bruker AC-250 instrument.

2.1. The Synthesis of Room Temperature Ionic Liquids. 1-Methylimidazole $(0.1 \mathrm{~mol})$ was added dropwise to 1 -chlorobutane $(0.2 \mathrm{~mol})$. The mixture was stirred vigorously and refluxed at $80^{\circ} \mathrm{C}$ for $24 \mathrm{~h}$. When the reaction was completed, the excess 1-chlorobutane was decanted and the crude ionic liquid was washed with chlorobutane $(2 \times 5 \mathrm{~mL})$. The trace of remaining 1-chlorobutane was removed with rotary evaporation at $60^{\circ} \mathrm{C}$ for $30 \mathrm{~min}$. The crude product was further purified by recrystallization (acetonitrile/ether) and dried under vacuum to give $[\mathrm{BMIM}]^{+} \mathrm{Cl}^{-}$. A solution of $[\mathrm{BMIM}]^{+} \mathrm{Cl}^{-}(0.1 \mathrm{~mol})$ in acetonitrile was added to a solution of sodium trifluoroacetate $(0.1 \mathrm{~mol})$ in acetone. The reaction 
TABLE 1: Preparation of thio-substituted nucleobase in various ionic liquids.

\begin{tabular}{|c|c|c|c|c|c|}
\hline Entry & Reactant 1 & Reactant 2 & Time & Yield (\%) & Ionic liquid \\
\hline 1 & 6-Mercaptopurine & Benzyl bromide & $0.5 \mathrm{~h}$ & 94 & {$[\mathrm{MeOEtMIM}]^{+}\left[\mathrm{CF}_{3} \mathrm{COO}\right]^{-}$} \\
\hline 2 & 6-Mercaptopurine & Benzyl chloride & $0.5 \mathrm{~h}$ & $88^{\mathrm{a}}$ & {$[\mathrm{BMIM}]^{+}\left[\mathrm{CF}_{3} \mathrm{COO}\right]^{-}$} \\
\hline 3 & 6-Mercaptopurine & 1-Bromopropane & $24 \mathrm{~h}$ & $72^{\mathrm{a}}$ & {$[\mathrm{BMIM}]^{+}\left[\mathrm{CF}_{3} \mathrm{COO}\right]^{-}$} \\
\hline 4 & 6-Mercaptopurine & 1-Iodobutane & $6 \mathrm{~h}$ & 94 & {$[\mathrm{MeOEtMIM}]^{+}\left[\mathrm{CF}_{3} \mathrm{COO}\right]^{-}$} \\
\hline 5 & 6-Mercaptopurine & 1-Iodobutane & $6 \mathrm{~h}$ & 89 & {$[\mathrm{BMIM}]^{+}\left[\mathrm{CF}_{3} \mathrm{COO}\right]^{-}$} \\
\hline 6 & 6-Mercaptopurine & 1-Iodobutane & $6 \mathrm{~h}$ & $\mathrm{n}$ & DMSO \\
\hline 7 & 6-Thioguanine & Benzyl bromide & $0.5 \mathrm{~h}$ & 88 & {$[\mathrm{MeOEtMIM}]^{+}\left[\mathrm{CF}_{3} \mathrm{COO}^{-}\right.$} \\
\hline 8 & 6-Thioguanine & 1-Iodobutane & $6 \mathrm{~h}$ & 92 & {$[\mathrm{MeOEtMIM}]^{+}\left[\mathrm{CF}_{3} \mathrm{COO}\right]^{-}$} \\
\hline 9 & 2-Mercaptopyrimidine & Benzyl bromide & $0.5 \mathrm{~h}$ & 93 & {$[\mathrm{BMIM}]^{+}\left[\mathrm{CF}_{3} \mathrm{COO}\right]^{-}$} \\
\hline 10 & 2-Mercaptopyrimidine & 1-Bromopropane & $24 \mathrm{~h}$ & 92 & {$[\mathrm{MeOEtMIM}]^{+}\left[\mathrm{CF}_{3} \mathrm{COO}\right]^{-}$} \\
\hline 11 & 2-Mercaptopyrimidine & 1-Bromopropane & $24 \mathrm{~h}$ & 92 & {$[\mathrm{PhOEtMIM}]^{+}\left[\mathrm{CF}_{3} \mathrm{CF}_{2} \mathrm{COO}\right]^{-}$} \\
\hline 12 & 2-Mercaptopyrimidine & 1-Bromopropane & $24 \mathrm{~h}$ & 83 & {$[\mathrm{BMIM}]^{+}\left[\mathrm{CF}_{3} \mathrm{COO}\right]^{-}$} \\
\hline 13 & 2-Mercaptopyrimidine & 1-Bromopropane & $24 \mathrm{~h}$ & $\mathrm{n}$ & DMSO \\
\hline 14 & 2-Mercaptopyrimidine & 1-Iodobutane & $6 \mathrm{~h}$ & 90 & {$[\mathrm{BMIM}]^{+}\left[\mathrm{CF}_{3} \mathrm{COO}\right]^{-}$} \\
\hline
\end{tabular}

${ }^{a}$ Reaction temperature was $60^{\circ} \mathrm{C}$. n: no isolated yield of product.

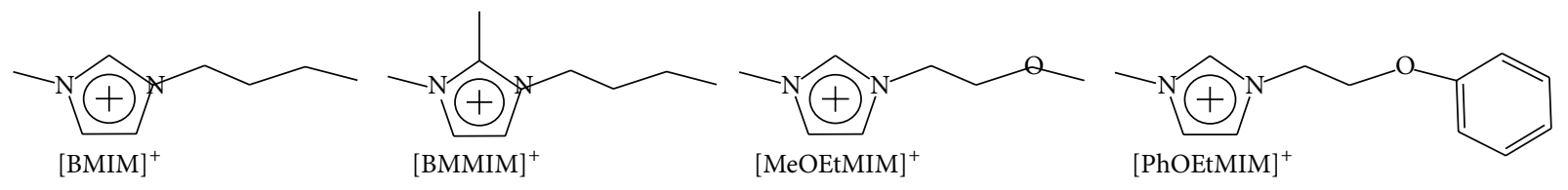

FIGURE 1: Chemical structure of the cations of ILs.

was continued for $4 \mathrm{~h}$. After that, the white solid $\mathrm{NaCl}$ was filtered off and the solvent was removed by rotary evaporation. The resulting product $\left([\mathrm{BMIM}]^{+}\left[\mathrm{CF}_{3} \mathrm{COO}\right]^{-}\right)$ was kept in a high vacuum to give a yield of $92 \% .96 \%$ of $[\mathrm{BMIM}]^{+}[\mathrm{Cl}]^{-}, 91 \%$ of $[\mathrm{MeOEtMIM}]^{+}\left[\mathrm{CF}_{3} \mathrm{COO}\right]^{-}, 90 \%$ of $[\mathrm{PhOEtMIM}]^{+}\left[\mathrm{CF}_{3} \mathrm{CF}_{2} \mathrm{COO}\right]^{-}, 95 \%$ of $[\mathrm{BMMIM}]^{+} \mathrm{Cl}^{-}$, and $91 \%$ of $[\mathrm{BMMIM}]^{+}\left[\mathrm{CF}_{3} \mathrm{COO}\right]^{-}$were prepared by a similar method [8].

2.2. Nucleobase Reactions. A thiopurine ( $1 \mathrm{mmol}$ ) and a halide $(1 \mathrm{mmol})$ were mixed in one of the ionic liquids. The reaction mixture was stirred for an appropriate time at $25^{\circ} \mathrm{C}$. When TLC analysis had indicated that the reaction was completed, water $(5 \mathrm{~mL})$ was added to the mixture. The resulting product was extracted with ethyl acetate (3 $\times 10 \mathrm{~mL})$ and the extraction was washed with water $(2 \times$ $10 \mathrm{~mL}$ ). Ethyl acetate was removed by rotary evaporation. The product was further dried overnight under vacuum. Water was removed under high vacuum rotary evaporation to afford the recovered ionic liquid.

\section{Results and Discussion}

In general, the thio-substituted nucleobase reaction of 6-mercaptopurine with benzyl bromide should be carried out with the use of triethylamine. Interestingly, it was found that ionic liquids had a catalytic activity to promote these reactions and satisfactory yields of products were obtained. Then a series of ILs such as $[\mathrm{BMIM}]^{+}\left[\mathrm{CF}_{3} \mathrm{COO}\right]^{-},[\mathrm{BMIM}]^{+}\left[\mathrm{BF}_{4}\right]^{-},[\mathrm{BMIM}]^{+}$ $\left[\mathrm{PF}_{6}\right]^{-}$, and $[\mathrm{MeOEtMIM}]^{+}\left[\mathrm{CF}_{3} \mathrm{COO}\right]^{-}, \quad[\mathrm{PhOEtMIM}]^{+}$
$\left[\mathrm{CF}_{3} \mathrm{CF}_{2} \mathrm{COO}\right]^{-}$(Figure 1) were investigated. ILs with the anion of $\left[\mathrm{CF}_{3} \mathrm{COO}\right]^{-},\left[\mathrm{CF}_{3} \mathrm{CF}_{2} \mathrm{COO}\right]^{-}$have a good solubility for all of the tested thionucleobases and ILs with the anions of $\left[\mathrm{BF}_{4}\right]^{-}$and $\left[\mathrm{PF}_{6}\right]^{-}$have a very poor solubility. The synthetic approach was straightforward. Thiopurines or thiopyrimidines and haloalkanes were mixed in one of the ILs. The mixture was stirred for an appropriate time at $25^{\circ} \mathrm{C}$ and the results were summarized in Table 1 . As expected, alkyl iodide was more reactive than alkyl bromide and chloride due to the nucleophilic order of halide ions. All reactions occurred in the ionic liquids at room temperature without any other catalyst.

As shown in Table 1, good yields of the products were obtained when the reactions were carried out in $[\mathrm{PhOPMIM}]^{+}\left[\mathrm{CF}_{3} \mathrm{CF}_{2} \mathrm{COO}\right]^{-},[\mathrm{MeOEtMIM}]^{+}\left[\mathrm{CF}_{3} \mathrm{COO}\right]^{-}$, and $[\mathrm{BMIM}]^{+}\left[\mathrm{CF}_{3} \mathrm{COO}\right]^{-}$. In contrast, very low yield of product was obtained in DMSO under the same reaction conditions. Surprisingly, when 2-mercaptopyrimidine was reacted with bromopropane in ILs, the resulting product of 2-propyl-mercaptopyrimidine was obtained. When they reacted in DMSO in the absence of triethylamine, no expected product was obtained, but a product of $\mathrm{Di}-2$ pyrimidinyl disulfide was observed.

Following the experiments above, it was supposed that the catalytic activities of ILs are related to the $\mathrm{C}(2)$ hydrogen on the imidazole ring. The thio-substituted reaction of 6-mercaptopurine with benzyl chloride was performed for $30 \mathrm{~min}$ and reaction of 6-mercaptopurine with 1bromopropane was performed for $24 \mathrm{~h}$ at $60^{\circ} \mathrm{C}$. As shown in Figure 2, with the same anion, a little higher yield of product 


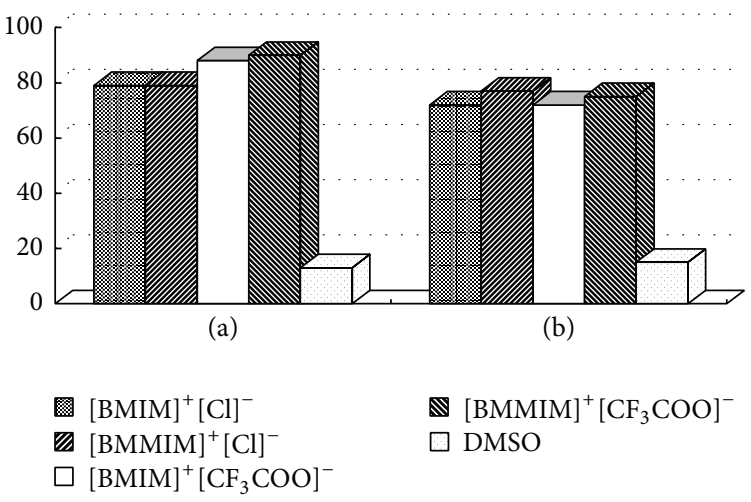

FIgURE 2: Reactions of 6-mercaptopurine with benzyl chloride (a) or 1-bromopropane (b).
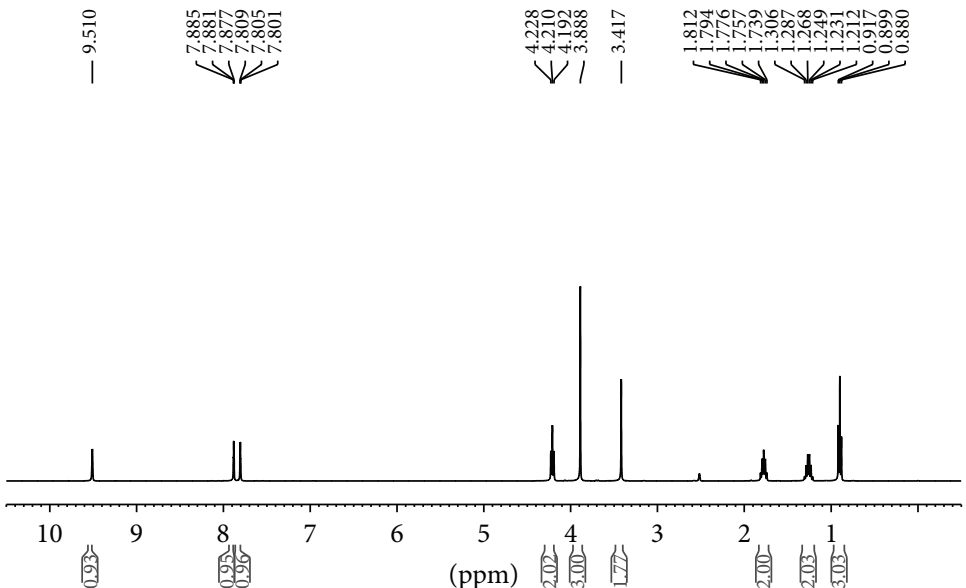

(a)

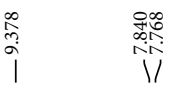
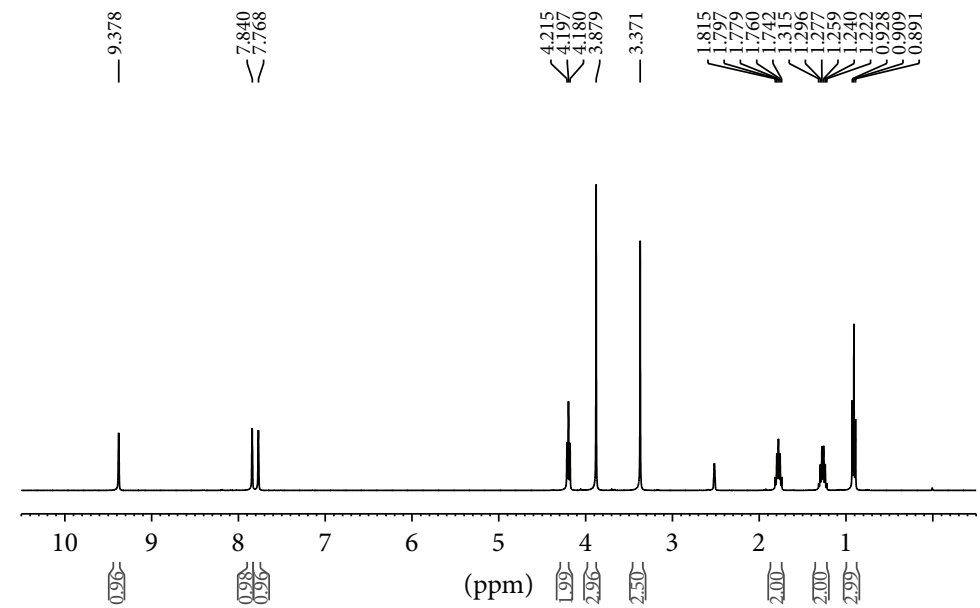

(b)

FIGURE $3:{ }^{1} \mathrm{H}$ NMR of $[\mathrm{BMIM}]^{+}[\mathrm{Cl}]^{-}$(a) and $[\mathrm{BMIM}]^{+}[\mathrm{Cl}]^{-}$with 6-mercaptopurine (b).

was observed with ILs in the order of $[\mathrm{BMMIM}]^{+}>[\mathrm{BMIM}]^{+}$ for both of the reactions. It indicated that the replacing of hydrogen using methyl decreases the activity of the hydrogen bond, which benefits the substituted reactions.

In addition, from ${ }^{1} \mathrm{H}$ NMR (Figure 3), the chemical shifts of $\mathrm{C}(2)$ hydrogen in the imidazole ring of $[\mathrm{BMIM}]^{+}[\mathrm{Cl}]^{-}$were
9.510. When 6-mercaptopurine was added to $[\mathrm{BMIM}]^{+}[\mathrm{Cl}]^{-}$, this chemical shift was moved to a lower position of 9.378 . Therefore, a supposed activity of IL was shown in Figure 4. When the hydrogen of $\mathrm{C}(2)$ of imidazolium ring was replaced by methyl, it lowered the hydrogen bond of cation and anion of ILs; the anion of ILs functions with the hydrogen 


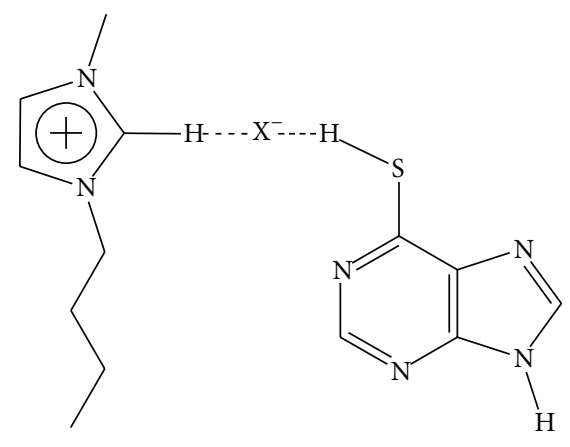

FIGURE 4: A supposed activity of the ionic liquid.

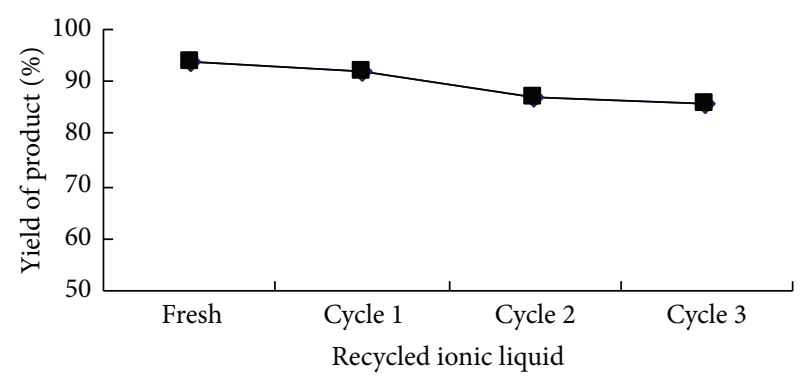

FIGURE 5: Reaction of 6-mercaptopurine with 1-iodobutane in the recycled $[\mathrm{MeOEtMIM}]^{+}\left[\mathrm{CF}_{3} \mathrm{COO}\right]^{-}$.

of thionucleobase was stronger, which accelerate the thiosubstituted reactions.

In order to determine whether recovered ionic liquids would affect the reaction rates or the yields of the products, reaction of 6-mercaptopurine with 1-iodobutane was carried out in the recycled $[\mathrm{MeOEtMIM}]^{+}\left[\mathrm{CF}_{3} \mathrm{COO}\right]^{-}$at room temperature for $6 \mathrm{~h}$. The reactions proceeded efficiently in the recovered ionic liquids as shown in Figure 5. RTILs could be reused without obvious decrease in both the product yields.

\section{Conclusions}

The thio-substituted reactions could be carried out effectively and efficiently in RTILs. The ionic liquids such as $[\mathrm{BMIM}]^{+}\left[\mathrm{CF}_{3} \mathrm{COO}\right]^{-}$and $[\mathrm{MeOEtMIM}]^{+}\left[\mathrm{CF}_{3} \mathrm{COO}\right]^{-}$are excellent reaction solvents as they provide good solubility and also generate excellent catalytic ability. Thionucleobases with different substituents are produced with excellent yields. The experimental approach is simple. Ionic liquids can be reused without significant decrease of yields. The approach has a great potential in their application in nucleoside chemistry.

\section{Conflict of Interests}

The authors declare that there is no conflict of interests regarding the publication of this paper.

\section{Authors' Contribution}

Xiaomei $\mathrm{Hu}$ and Bixian Zhang contributed equally to this work. Both of them are first authors.

\section{Acknowledgments}

This work was financially supported by Heilongjiang Human Resources and Social Security for the Scientific Research Foundation of Returned Overseas Chinese Scholars, Heilongjiang Postdoctoral Foundation (LBH-Q13019), and Northeast Agricultural University Doctoral Foundation (2010RCB58).

\section{References}

[1] G. B. Elion, G. H. Hitchingsg, and H. Vanderwerff, "Antagonists of nucleic acid derivatives VI. Purines," The Journal of Biological Chemistry, vol. 192, no. 2, pp. 505-518, 1951.

[2] G. B. Elion and G. H. Hitchings, "The synthesis of 6-thioguanine," Journal of the American Chemical Society, vol. 77, no. 6, p. 1676, 1955.

[3] G. H. Elgemeie, "Thioguanine, mercaptopurine: their analogs and nucleosides as antimetabolites," Current Pharmaceutical Design, vol. 9, no. 31, pp. 2627-2642, 2003.

[4] J. L. Kelley, E. W. McLean, R. M. Ferris, and J. L. Howard, "Benzodiazepine receptor binding activity of 6,9-disubstituted purines," Journal of Medicinal Chemistry, vol. 32, no. 5, pp.10201024, 1989.

[5] V. Kumar, V. S. Parmar, and S. V. Malhotra, "Enhanced solubility and selective benzoylation of nucleosides in novel ionic liquid," Tetrahedron Letters, vol. 48, no. 5, pp. 809-812, 2007.

[6] X. M. Hu, Y. B. Xiao, K. Niu, Y. Zhao, B. X. Zhang, and B. Z. $\mathrm{Hu}$, "Functional ionic liquids for hydrolysis of lignocellulose," Carbohydrate Polymers, vol. 97, no. 1, pp. 172-176, 2013.

[7] X. M. Hu, B. X. Zhang, Z. Yuan, and B. Z. Hu, "Functional ionic liquids as effective catalysts for the preparation of genistein and daidzein," Journal of Food, Agriculture and Environment, vol. 11, no. 2, pp. 193-196, 2013.

[8] X. M. Hu, "Study on the synthesis of six ionic liquids," Journal of Northeast of Agricultural University, vol. 42, no. 8, pp. 142-145, 2011. 

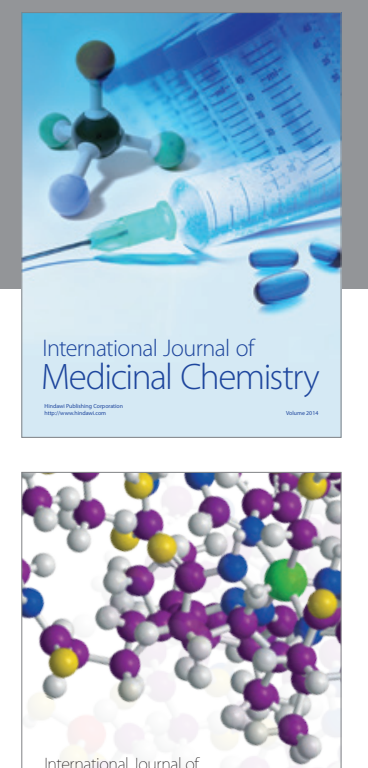

\section{Carbohydrate} Chemistry

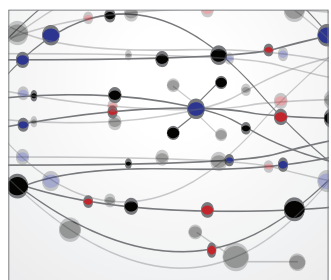

The Scientific World Journal
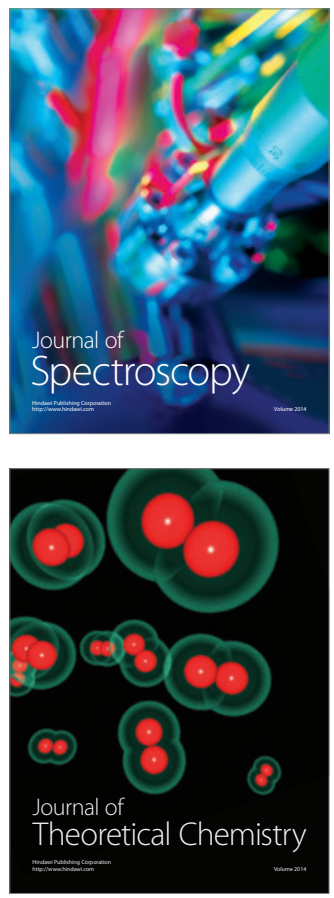
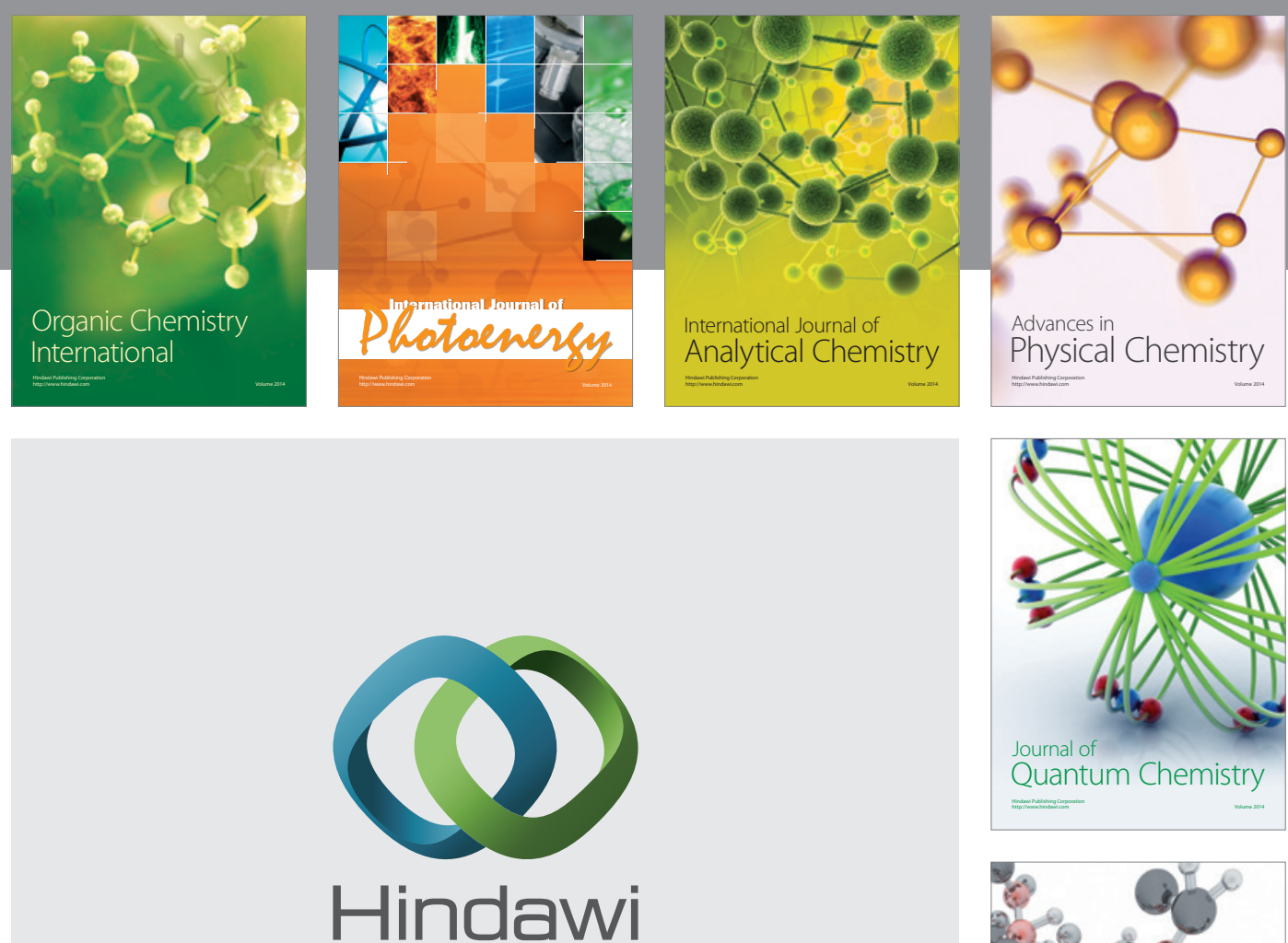

Submit your manuscripts at

http://www.hindawi.com

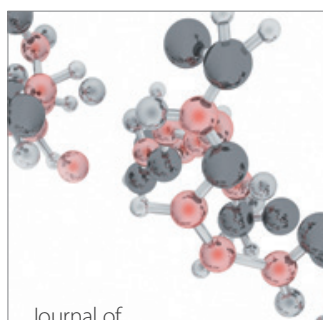

Analytical Methods

in Chemistry

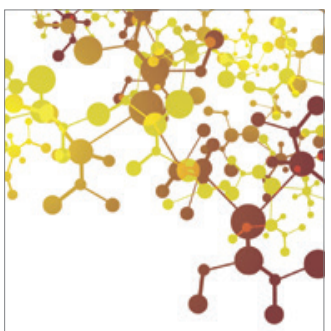

Journal of

Applied Chemistry

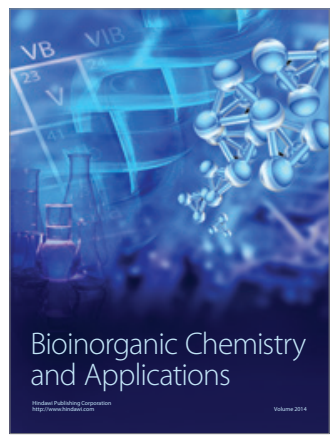

Inorganic Chemistry
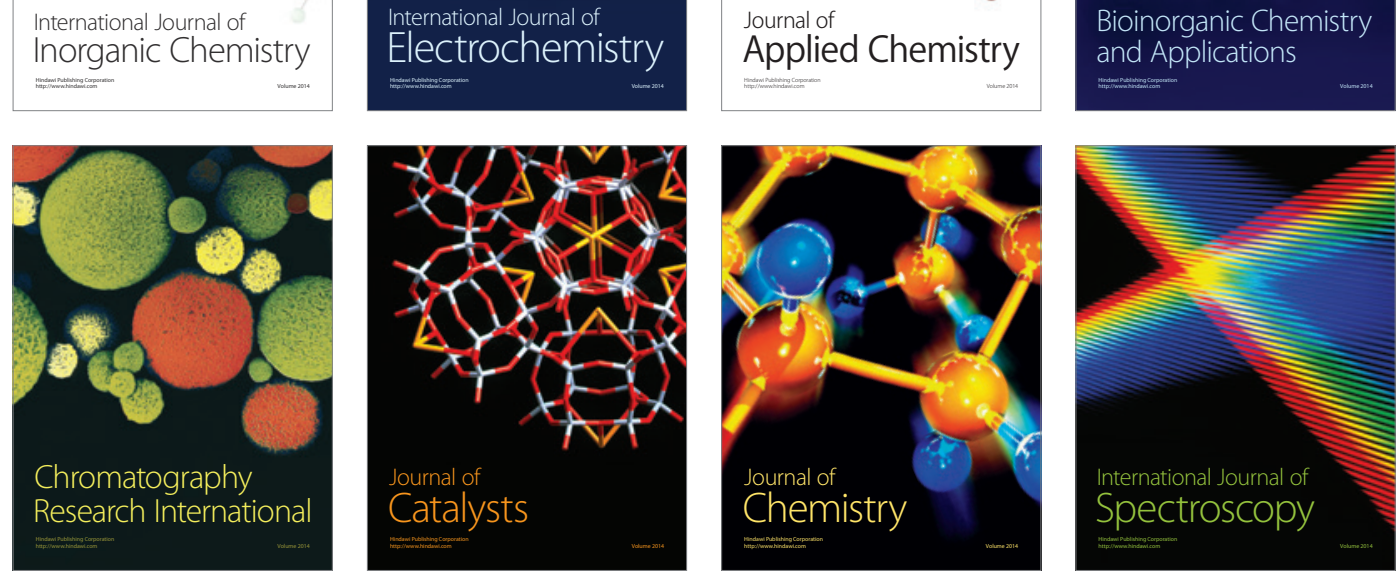